\title{
Lumen
}

Selected Proceedings from the Canadian Society for Eighteenth-Century Studies

\section{Gender Inversions in Haywood's The Distress'd Orphan, or, Love in a Mad-house}

\section{Earla A. Wilputte}

Volume 14, 1995

URI : https://id.erudit.org/iderudit/1012508ar

DOI : https://doi.org/10.7202/1012508ar

Aller au sommaire du numéro

Éditeur(s)

Canadian Society for Eighteenth-Century Studies / Société canadienne d'étude du dix-huitième siècle

ISSN

1209-3696 (imprimé)

1927-8284 (numérique)

Découvrir la revue

Citer cet article

Wilputte, E. A. (1995). Gender Inversions in Haywood's The Distress'd Orphan, or, Love in a Mad-house. Lumen, 14, 49-61. https://doi.org/10.7202/1012508ar d'utilisation que vous pouvez consulter en ligne. 


\section{Gender Inversions in Haywood's The Distress'd Orphan, or, Love in a Mad-house}

The amatory novellas of Eliza Haywood have been assessed by critics as the works of a feminist champion reiterating the myth of feminine virtue in distress and the social dichotomy of persecuted Woman and lecherous Man. John Richetti's descriptions of Haywood's early works (1719-29) stress gender polarities: 'female innocence destroyed by a world of male corruption'; 'an organized male conspiracy'; 'unscrupulous masculine cunning'; and 'male tyranny versus female virtue'. ${ }^{1}$ Similarly, Mary Anne Schofield discovers in these novellas 'a picture of mistreatment and selfish manipulation of the female by the male and the chauvinistic attitudes of society. ${ }^{2}$ But Haywood does not always present man and woman in such stark opposition, nor does she consistently condemn man as monster. Often, Haywood shows that the eighteenth-century determination to maintain the social and sexual hierarchy works against men as well as women.

While Haywood exposes the homosocial bonding that apparently makes women irrelevant except as they define masculinity, in many works she transforms and absorbs her female characters into male ones. Gender ambiguity within Haywood's works reveals her narrative struggle to convey the similarities between the sexes by destabilizing the gender dichotomies as well as to make the injustices done women more obvious when we consider the similarities. Hélène Cixous applauds such destabilization as 'the other bisexuality', wherein bisexuality is defined as 'each one's location in self ... of the presence ... of both sexes. ${ }^{4}$ Cixous states that 'it is women who are opening up to and benefiting from this vatic bisexuality which doesn't annul differences but stirs them up' (1096) and within some of Haywood's novellas we find both villainesses and heroines who adopt a masculine role to emphasize the differences between genders. While masculinity and femininity are predominantly at odds in Haywood's works, her narrative strategy is often more complex than this simple opposition. Haywood's novellas play upon stereotypical masculine and feminine traits to expose her society's modes of sexual perception. Although the surface story may tell of an indomitable 
heroine and relate an escapist feminine fantasy, as Richetti and Schofield note, one of Haywood's messages is that men efface the feminine identity. What should not be overlooked, however, is the way in which narratological structures such as parallelism and cross-sexual character doubles, as well as the themes of homosociality and homoerotic suggestion reveal Haywood's interest in promoting social relationships based on equality. Cross-dressing, disguise, and the absorption of female characters into male ones allow Haywood's female readership to experience vicariously masculine power and consider the essential similarities between the sexes. Thus, Haywood is not employing merely negative images of Woman, reinforcing eighteenth-century woman's non-existence and lack of identity in a masculine world. Neither can Haywood's early amatory novellas be dismissed as 'a supplement to life rather than a coherent comment on $i{ }^{5}$ for she anticipates the prescriptions of such socially concerned women as 'Sophia', who writes that patriarchal 'Interest' and 'custom' are the source of 'vulgar errors' in society:

such is the prevalency which custom, ever so wrongly introduced, has over the minds of the Men, that it requires much less difficulty to wean them from sentiments, which they themselves have built on the most convincing evidences of reason and truth, than to draw them from the prejudices which custom has instilled into them. ${ }^{6}$

For Haywood, sexual stereotyping is as limiting for men as it is for women and in her early fictions she strives to present a socially relevant and coherent commentary on the need to rectify the sexual imbalance. An examination of the 1726 novella, The Distress'd Orphan, or Love in a Mad-house and a look at some of her other early works, reveal Haywood's special interest in equality between the sexes and her fictional solution of gender inversion.

The Distress'd Orphan is a conventional romance in structure. It is the story of Annilia who is brought up by her uncle Giraldo, alongside her cousin, Horatio. Giraldo attempts to develop an affection between the cousins based on mutual experience and education so that they will marry and thus keep Annilia's estate in his family. Annilia is close to yielding to her guardian's request for this arranged marriage when she and a young Colonel Marathon fall in love. When Annilia refuses to marry Horatio, Giraldo confines her to a private madhouse. After more than fourteen weeks she is rescued by her lover, marries him, and together they expose the villainy of her uncle. The plot is simple; the conclusion happy. However, Haywood utilizes the comic structure and 
the concluding marriage to manifest the shortcomings of relations between the sexes.

Despite its apparent focus on the heroine, Haywood's novella works to nullify the central feminine figure while concentrating on the homosocial ties between the male characters. Annilia's name comes from the Latin nihil, nil. 'Nothing' also describes her legal and social status as orphan and woman as it denotes 'comparative insignificance or unimportance; a thing (or person) not worth reckoning, considering, or mentioning;' and finally, to benefit Giraldo's plot, it means 'mental inferiority' (OED). While on the surface The Distress'd Orphan tells the story of a strong-minded, virtuous young woman who will not compromise her principles or her love, a deeper reading reveals that the female character matters little to the plot and is essentially silenced by being absorbed into the male protagonist halfway through the narrative.

Antithetical to the concepts of homosociality and mastery is the idea of equality which Haywood manages to investigate within the same text. Haywood employs the words 'equal' and 'equality' thirteen times over sixty-three pages, repetitions which foreground the significance of the theme. The Distress'd Orphan plays with the notion of equal lovers matching wits with equal adversaries. We are told that 'Passion equals all things', ${ }^{7}$ but it is also implied that being in love is equivalent to madness. Annilia and Marathon are 'equally charming, equally charmed' (10) and love with 'equal Ardency' (11); however, they also share characteristics with the villains. Horatio is Annilia's 'Equal in every thing but Wealth' (6), while the girl is capable of being as 'equally incensed' as her uncle (25). Marathon is 'possessed of a Fortune equal to that of Horatio' (25) and 'alledge[s] an equal Plea for Favour' from Annilia (24). These instances of equality are based, for the most part, on the upbringing and emotional states of the characters and they underscore the unfairness of Giraldo's misogynistic treatment of Annilia. But equivalence also introduces the possibility that Marathon's interest in Annilia is as mercenary as Giraldo and Horatio's. For a time, the reader distrusts the true lover, afraid that Marathon, too, may be manipulating Annilia. The reader finds herself prejudging the good Colonel based on the sexual types of the disingenuous lover and cunning man. In this way, Haywood shows that the socially imposed polarization of the sexes works against men as well as women; but she also reveals other problems.

Equivalence is introduced to expose male dominance. Despite Annilia and Horatio's equal education and upbringing and her superior fortune, she is powerless to stop the machinations of her uncle simply because she is a woman. Judith Drake, in her 'Essay in Defence of the Female Sex,' 
had touched upon this theme of sexual equality thwarted by masculine jealousy as early as 1696 :

Men being sensible as well of the Abilities of Mind in our Sex, as of the strength of Body in their own, began to grow Jealous, that we, who in the Infancy of the World were their Equals and Partners in Dominion, might in process of Time, by Subtlety and Stratagem, become their Superiors; and therefore, began in good time to make use of Force (the Origine of Power) to compell us to a Subjection, Nature never meant ... ${ }^{8}$

Haywood herself returns to the theme of imposed inequality between the sexes in her Female Spectator (1744-46):

The objection that I have heard made by some men that learning would make us too assuming, is weak and unjust in itself, because there is nothing would so much cure us of those vanities we are accused of, as knowledge. $\mathrm{O}$, but, say they, learning puts the sexes too much on an equality, it would destroy that implicit obedience which is necessary the women should pay to our commands. If once they have the capacity of arguing with us, where would be our authority? Now will I appeal to any impartial reader, even among the men, if this very reason in keeping us in subjection does not betray an arrogance and pride in themselves, yet less excusable than that which they seem so fearful of our assuming. ${ }^{9}$

In The Distress'd Orphan, Haywood takes her condemnation of sexual inequality even farther by pairing up and contrasting variations of socially-defined masculine and feminine traits between characters. Annilia transgresses the bounds of femininity when she desires the right to live her own life. Her 'Vehemence' (21), 'little Remains of Patience; an Air wholly composed of Fierceness' (22), in addition to her decisively packing up her clothing and jewels to leave her guardian's house, lead to Giraldo's plan of suggesting Annilia is mad because she does not behave in a feminine fashion. Of course, we are meant to see Giraldo's claim as an abuse of masculine power, but Haywood also stresses that women are severely limited by social constructions of feminine behaviour.

Foucault identifies behaviour like Annilia's as the 'madness of vain presumption' in which the mad person identifies with herself 'and by means of a delusive attachment ... grant[s] [her]self all the qualities, all the virtues or powers [s] he lacks. ${ }^{, 10}$ In a sense, Annilia is mad because she thinks she can act with the same privilege as a man. While she does possess qualities which make her equivalent if not superior to her cousin, she grants herself what her society perceives as masculine rights. Unwilling to be restricted by the sexual double standard, she becomes what 
Defoe's Roxana calls a 'Man-Woman'. Roxana said: 'seeing Liberty seem'd to be the Men's Property, I wou'd be a Man-Woman; for as I was born free, I wou'd die so.' ${ }^{11}$ Annilia's decision to pursue her own desires is not as militant nor as promiscuous as Defoe's heroine; however, her resolve, in Haywood's comic structure of stereotypes, renders her a 'masculine' woman.

The homosocial, filial bond between Giraldo and Horatio is threatened by Annilia's uncooperative, 'masculine' character. Her personality and her alliance with Marathon determine Giraldo to assert his mastery over the lovers. He tells Annilia, 'I have good reason to believe your Indiscretions have of late rendred you liable to the Censure of the World, and must therefore restrain that Liberty you have but too much abused' (32-33). He confines her, though, for what she might do; namely, marry Marathon or sully his own patriarchal reputation by running away with her lover. In this way, Giraldo is not unlike Alibius in The Changeling (1622), Pinchwife in The Country Wife (1675), Squire Western in Tom Jones (1749) and the Harlowes in Clarissa (1747-48), all of whom lock up their women to ensure their own wills. ${ }^{12}$ Interestingly, it is the weakness of the men that is exposed as they attempt to subordinate the women. These men are invariably defeated by a more powerful or wily man such as Franciscus, Horner, Tom and Lovelace. In this way, rivalry with other men often becomes more important than the love for a woman. At this point, the woman, no matter whether a Margery Pinchwife or a Sophia Western, becomes negligible in the homosocial equation; she is merely a factor which defines the masculinity of the male characters. Even Haywood's hero, Colonel Marathon, enjoys flaunting his success with Annilia in the faces of Giraldo and Horatio so that his indiscretion and boldness put Annilia at risk $(17,20)$.

But even the masculine traits that make Annilia an admirable heroine are no match for Giraldo because Annilia is a woman. Though perceived as equivalent, they are not equals due to their sex. Haywood shows that Annilia's characteristics must be downplayed and eventually abandoned, for otherwise, her society perceives her as mad. Likewise, Haywood's readers would find Annilia's behaviour, although right in principle, too aggressive. ${ }^{13}$ To achieve the proper comic closure, Haywood must show the ideal, companionate marriage of hero and heroine as well as between masculine and feminine qualities. Playing within the structure of sexual stereotypes, Haywood must not allow her heroine to be construed as too masculine yet she needs her to close the gap of the gender dichotomies to an acceptable degree.

One way in which Haywood manages this problem is to play with the rigidly polarized stereotypes of masculinity and femininity and then substitute a male character for a female one. This complex type of gender 
inversion allows the reader to view the consequences of sexual inequality from a unique perspective. In The Distress'd Orphan, Annilia is placed in the madhouse and replaced in her relationship with Marathon by the manservant, Osephas. Fired by Giraldo for acting as the go-between for the lovers, Osephas becomes Marathon's help-mate and is made distinctively feminine through the text's language. He is described in wife-like terms that emphasize his subservience, allegiance and gratitude:

He found so much difference between these two Masters [Giraldo and Marathon], that the Goodness of the latter engaged him in Ties more strong than those of Duty; there was nothing he would not have done to procure him Satisfaction (45).

In Philidore and Placentia (1727), Haywood again attempts to subvert the stark opposition of masculinity and femininity. The masculinely aggressive mistress is silenced in the text and supplanted by a feminized male character. On his travels, Philidore meets and rescues the Christian eunuch who is described in feminine terms such as 'the lovely stranger ${ }^{14}$ and the 'beautiful unknown' (195). Like Osephas' strong attachment to Marathon, Philidore is 'attached to [the youth] by an impulse which he could not at that time account for' (188) and he 'threw himself by him on the ground, hung over him, bathed his face in tears, uttered a thousand incoherent and extravagant exclamations' (189). Despite the homoerotic suggestion of the quotation, the attachment between Philidore and the eunuch allows Philidore once again to act the part of the hero, saving the weak from the powerful. In each of these relationships, the hero is permitted to play the dominant, masculine role, reasserting his social, indeed, homosocial significance which may have been in question in the love relationships with the strong women. Marathon is Osephas' master; Philidore is the Christian eunuch's saviour. Interesting, however, is the fact of reciprocity and interdependence in these new relationships. Marathon and Philidore's reliance upon and willingness to learn from their inferiors, Osephas and the eunuch, help them to achieve their ultimate happiness with the women they love. The subordinate males here - the socially unempowered servant and the emasculated youth - become textual surrogates for the 'masculine' women. Through Osephas and the eunuch (Annilia's servant and Placentia's brother, respectively) the women reveal the usefulness of their masculine qualities to their lovers. In this way, although the female characters appear to be abandoned by the narrative, they have actually been transformed into more acceptable, less threatening male characters who act for them. Thus, Haywood attempts to work out an egalitarian relationship between the sexes by making heterosexual relationships homosocial ones. 
Haywood's positive portrayals of Marathon, Osephas, Philidore, and the Christian eunuch suggest that egalitarianism is possible not only among men but between men and women. Haywood suggests that rather than using homosocial and heterosexual desire to dominate others, there should be a coming to terms with, and an appreciation of, the feminine and masculine qualities in women and men.

The concept of 'the other bisexuality' is most explicit in The Fatal Secret: Or, Constancy in Distress (1724). Haywood describes the lovers:

The natural Boldness of Manhood was in him sweetly temper'd with a more than female Softness; and the Tenderness and Bashfulness incident to Womankind, in her was mingled with something of a manly Majesty of Thought. ${ }^{15}$

Again, Haywood emphasizes the human balance and benefit that is achieved through the sharing of masculine and feminine attributes: there is an intellectual as well as sexual union between the sexes. Like the complementary natures of Marathon and Annilia, the characters of the lovers in The Fatal Secret work together rather than permitting one to dominate their relationship: 'the prodigious Awe which Love always inspires, kept either from believing they had the Power of conquering' (212). The result is a companionate relationship.

Earlier, in The Injur'd Husband; or, the Mistaken Resentment (1722), Haywood concretizes the androgynous image by allowing the wronged woman, Montamour, to disguise herself as a man. Unbeknownst either to the reader or the injured husband Beauclair, Montamour (as the young man 'Vrayment') explains how the world wrongs women. In this way, Montamour explains herself and is heard as an equal. The effect of 'Vrayment' (Truth) on Beauclair is both spiritual and suggestively physical:

Never Man, overwhelm'd like him in sorrows, met a Comforter so kind, so industrious, and so artful in allaying them; he look'd on him as his GuardianAngel, sent down from Heaven to soften his impetuous Passions, and restore his Peace. It was seldom they were asunder, but whenever it happen'd so, each seem'd to want the better half of himself: - They eat together,-drank together; and Beauclair wou'd very fain have persuaded him to take Part of his Bed: But the other excus'd himself from that. ${ }^{16}$

Here, as in Philidore's strong attachment to the Christian eunuch and Osephas' wife-like affection for Marathon, the suggested homoeroticism draws attention to a heterosexual relationship based upon equality and mutuality between the hero and the woman whom the man represents. 
Haywood's emphasis is again on a completeness that is spiritual as well as physical.

In The Distress'd Orphan, besides being the heroine's textual surrogate, Osephas' role is to keep Marathon from pursuing specifically homosocial avenues of regaining Annilia while also helping him to keep the woman's safety in view. Marathon finds that in any competitive, homosocial conflict, his own masculinity would fall short. Giraldo's 'very great ' fortune would exhaust Marathon's 'slender Fortune' in the law courts (46). When Marathon considers challenging Horatio to a duel in the hope that 'his Antagonist would be glad to purchase his Life at the expence of the secret' of where Annilia was kept (46-47), Osephas reminds him of several consequences Marathon has not considered: falling by Horatio's sword and leaving Annilia defenceless; or, killing Horatio and being punished by the law for instigating the duel so that Annilia would again be left friendless. Through Osephas, Marathon learns that 'Subtilty, and not Force' (49) must be the means by which to rescue Annilia; that is, he must employ essentially feminine rather than masculine methods. The Colonel disguises himself as a lunatic, Lovemore, and is admitted to the madhouse with his servant, renamed Andrew.

John Bender describes prisons, shut-up houses and madhouses as 'liminal places': 'etymologically, "seclusion sites" ... The inmates are at once neither living nor dead and both living and dead ... the randomness, the reign of chance, and confusion of categories so abhorrent to reformers prevails horrifyingly. ${ }^{17}$ In Haywood's madhouse, the randomness and chaos are realized as being at once both masculine and feminine and neither masculine nor feminine, as Annilia and Marathon are equalized - both considered mad and nothing more - within its walls. Annilia is surrounded not with men and women but 'Howlings like that of Dogs, Shoutings, Roarings, Prayers, Preaching, Curses, Singing, Crying, promiscuously join'd to make a Chaos of the most horrible Confusion' (42). This is the 'confusion of categories' that Bender describes and that so frightens the homosocial, androcentric society outside the madhouse's confines. The inmates and the keepers are dehumanized, referred to as 'Wretches,' 'helpless Objects of Compassion,' 'inhuman Creatures' (42), and 'pityless Monsters' (43) respectively. The outside world structures the madhouse into feminized inmates and masculinized keepers in an attempt to exert control over the chaos and disempower the confused categories. Annilia's refusal to wed Horatio and her 'mad,' masculine insistence that she has the right to live her own life anger Giraldo because she disrupts the homosocial balance of power. By forcibly committing Annilia to the asylum, Giraldo tries to renormalize her femininity and reestablish the dichotomy of the sexes. 
Schofield suggests that the madhouse in The Distress'd Orphan 'functions as a symbolic matrix for the author's statements about the fate of women, that is, imprisonment mirrors both their physical and mental fetters. ${ }^{18}$ Haywood, then, would be using what becomes a familiar paradigm in 18th-century literature: Belinda's Cave of Spleen (1714) with its domestic images of entrapped women; the brother-husband of Moll Flanders threatening her with the madhouse in Virginia for her unwifely behaviour (1724); Burney's Cecilia's derangement and loss of voice (1782); and Maria's forcible confinement in the mental asylum in Wollstonecraft's The Wrongs of Woman (1798). All of these examples, including The Distress'd Orphan, show women's socially enforced liminality and Haywood makes the point more explicit by drawing the parallel between wives and lunatics in English law: Giraldo 'had the same Pretensions to her Estate while [she was] suppos'd a lunatick, as his Son would have if made her Husband' (38); that is, neither wife nor lunatic may possess her own estate. In addition, the Chancery 'exercised wardship over orphans and lunatics, ${ }^{19}$ making even Annilia's fatherless state equivalent to lunacy.

But Haywood also employs the private madhouse in a different way than Schofield suggests: she illustrates the lunacy of the world at large in its treatment of women and its pursuit of power. Annilia does not give way to 'mental fetters'; she 'resolved rather to die than yield to put a greater power into the hands of Persons, who had made so detestable a Use of what they had already' (43). Annilia also consoles herself: 'tho' it was infinite Trouble to her to think that they enjoy'd [her Wealth], yet the Satisfaction it gave her to reflect that he [Horatio] had not her Person also, very much alleviated the Pain' (44); 'had the Marriage Ceremony past, all had been irrevocably lost, and I undone beyond all hope of Vengeance or Redress' (44). Annilia's state of mind suggests that it is madness to marry where one does not love, and that homosociality is a barbaric custom that sacrifices women's identities to its own masculine appetite.

Haywood also shows that within this inverted, reversed world of the madhouse, men do not pursue social bonds with men but with women. Marathon puts Annilia's interest first and Osephas must go through the maids to gain access to Annilia. The only way a message can be delivered to her is by Osephas' attaching a note to a little boy's arrow and shooting it with a bow through the bars of Annilia's window. The allusion to Cupid brings to the fore the powers of Venus and the significance of the heterosexual bond. Haywood's madhouse may, indeed, be a 'symbolic matrix' as Schofield suggests; however, it works in a more positive way than merely pointing out the injustice of male dominance and the abuse of masculine power. Haywood illustrates the great social advantage that 
could be precipitated by an egalitarian allegiance between men and women: out of such a 'matrix' of confusion and chaos could emerge a world of equipoise.

After Annilia is rescued from the madhouse, Osephas, predictably, fades away as he is no longer necessary as Marathon's helpmate. Annilia apparently regains her status of equality and her reputation for reason by setting her affairs in order: 'she told [Marathon] that as soon as Morning arrived ... she would put it past the power of the whole World to separate them for the future, by becoming his by those Tyes, which are not to be dissolv'd but by Death'; she summoned her friends to witness the wedding and 'hear a Story full of Wonder' (60); and finally, she 'reproach'd [Giraldo] with his Usage of her, and demanded the Writings of her Estate' (61). But lest Annilia still sound too masculine, Haywood offers qualifying terms to emphasize her partnership with Marathon. We are told that Annilia proposes marriage because 'not only her Inclinations, but her Reputation also ... induc'd her to make him' her husband; that is, their mutual needs are met in her 'Performance of that Promise' (60). Annilia's reproach of her uncle is made 'in mild Terms' and when she demands the writings of her estate, she adds that those writings 'are now the Right of my Husband, pointing to Colonel Marathon' (61). Annilia must rein in her temper to become a good and dutiful wife.

Although there is no indication that the conclusion is ironic, it is unsettling rather than happy. The union of Marathon and Annilia, their 'other bisexuality' coming together to form a complete, egalitiarian couple, may seem to promote the ideal of the companionate marriage, but difficulties remain. Haywood's comic ending may be read as a deepening of her criticism of the abuses of the patriarchal order as Annilia's problems can be solved only through the conventional righting of those wrongs in marriage. Custom must be appeased and Annilia's 'Reputation ... induc'd her' to wed the man with whom she ran away. In addition, her estate becomes her husband's and she functions merely as the conduit of it from Giraldo to Marathon. While the transforming of Annilia's masculine qualities into the character of Osephas showed their benefits to Marathon, the disadvantages of femininity are manifested when Annilia replaces Osephas. Annilia, in her turn, becomes Marathon's servant, acting on his behalf in demanding from Giraldo the writings of her estate. The reader must be dissatisfied with Annilia's conservative end, a dissatisfaction Haywood ensures with her shift from the marriage back to the villains.

The Distress'd Orphan ends like a moral tale: 'The ill Success of Giraldo's Designs, together with the Shame and Disreputation, which the Discovery of his late Proceedings had drawn on him, threw him into a Fever, 
of which he died' (62). 'His Son Horatio being accounted equally blameable, not able to endure the Reproaches which were daily made him ... left the Kingdom, and has not since been heard of' (63). Giraldo and his son are finally made equals but have been destroyed by the homosocial power they sought to control. On the surface, the conclusion rewards the lovers and punishes the villains. However, the hasty closure distributing divine justice is not a particularly reassuring 'supplement to life' (as Richetti claims Haywood's fictions are) because it jars so against reality. The reader's uneasiness with Annilia's marriage is increased with the descriptions of Giraldo and Horatio's punishments. The implication of the text's language is that homosocial culture condemns Giraldo and his son for failing to succeed in their plot to dominate Annilia, not for the immorality of their designs. In the same way that Giraldo cannot permit Annilia and Marathon to destabilize the homosocial order by marrying against his wishes, 'society' cannot permit Giraldo and Horatio to expose the homosocial machinery when they fail in their scheme.

The narrator's closing wish for Annilia and Marathon, that recompence and happiness triumph 'over those who seek or to detract, or to prejudice them' (63), is Haywood's own wish for a happy ending. However, behind the wish and the providential and social punishments of the villains is the knowledgeable comment on real life: the homosocial system of power remains intact and continues to control lives and relationships.

EARLA A. WILPUTTE

St. Francis Xavier University

Notes

1 John Richetti, Popular Fiction before Richardson: Narrative Patterns 1700-1739 (Oxford: Clarendon Press, 1969) 169, 181, 187.

2 Mary Anne Schofield, Eliza Haywood (Boston: Twayne, 1985) 44.

3 Eve Kosofsky Sedgwick, Between Men: English Literature and Male Homosocial Desire (New York: Columbia UP, 1985), states that "'Homosocial" is a word occasionally used in history and the social sciences, where it describes social bonds between persons of the same sex ... In fact, it is applied to such activities as "male bonding" ...' (1). My use of the term also incorporates Heidi Hartmann's definition of patriarchy as cited in Sedgwick: 'relations between men, which have a material base, and which, though hierarchical, establish or create interdependence and solidarity among men that enable them to dominate women' (3).

4 'The Laugh of the Medusa,' The Critical Tradition: Classic Texts and Contemporary Trends, ed. David H. Richter (New York: St. Martin's Press, 1989) 1096. 
5 Richetti (n.1) 183.

6 Sophia (pseud.), Woman Not Inferior to Man (1739) (London: Bentham Press, 1975) 6.

7 The Distress'd Orphan, or Love in a Mad-house 3rd ed. (London: J. Roberts, 1726) 25. All further references are to this edition and will be noted in the body of the text.

8 Cited in The Other Eighteenth Century: English Women of Letters 1660 - 1800, eds. Robert W. Uphaus and Gretchen M. Foster (East Lansing: Colleagues Press, 1991) 30 .

9 The Female Spectator being Selections from Mrs. Eliza Heywood's Periodical (1744-1746), ed. Mary Priestley (London: John Lane The Bodley Head Ltd., 1929) 62.

10 Michel Foucault, Madness and Civilization: A History of Insanity in The Age of Reason (New York: Vintage Books, 1973) 29.

11 Daniel Defoe, Roxana, ed. David Blewett (Markham: Penguin, 1982) 212 (first published 1724). More extreme but equally unsympathetic examples of 'masculine' women can be found in satirical send-ups such as Aunt Western in Tom Jones (1749) and Tabitha Bramble in Humphry Clinker (1771).

12 Real-life examples of this practice are harrowing. Allan Ingram, The Madhouse of Language: Writing and Reading Madness in the 18th-Century (London: Routledge, 1991) 40-43, cites Dr. Patrick Blair's 1725 pamphlet which details the 'cure' of a madwoman who would not take up her role of wife nor answer to her husband's name. Blair's treatment involved the patient's being stripped, blindfolded and fixed to a chair in a bathing tub whereupon 'in 90 minutes there was 15 Ton of water let fall upon her' (42). Blair declares he will release her 'provided she would go to bed with her husband that night, which she did with great chearfullness' (42). See also 'The Hardships of the English Laws in relation to Wives' (1735) which details the case of Mr. Veezey who 'confined his Wife for some Years in a Garret, without Fire, proper Cloathing, or any of the Comforts of Life ... frequently Horse-whipt her; that her Sufferings were so great and intolerable, that she destroyed her wretched Life by flinging herself out at the Window.' Veezey was acquitted for murder because he had not pushed his wife out the window himself, and he had left her 'hard and mouldy' bread in the room 'supposed sufficient to sustain Life'; cited in Women in the Eighteenth Century: Constructions of Femininity, ed. Vivien Jones (London: Routledge, 1990) 219.

13 One is reminded of Restoration heroines such as The Country Wife's Margery Pinchwife who is dressed up in men's clothing (III.ii) which serves to emphasize her sex while revealing her aggressive, yet simple-minded, pursuit of Horner. Even more sane female leads such as The Man of Mode's Harriet who is described as wild and witty and The Way of the World's effervescent Millamant must eventually be subdued so that they might 'dwindle into a wife.' Even Fielding's Sophia shocks Honour when she plans her escape from her father's house and Clarissa's determined avoidance of an unwanted marriage is not condoned by her society.

14 'Philidore and Placentia; or L'Amour Trop Delicat,' Four Before Richardson: Selected English Novels, 1720-1727, ed. William H. McBurney (Lincoln: U. of Nebraska 1963) 189. All further references to this edition will be noted in the body of the text. 
15 Masquerade Novels of Eliza Haywood, intro. Mary Anne Schofield (Delmar, N.Y.: Scholars' Facsimiles \& Reprints, 1986) 212.

16 Four Novels of Eliza Haywood, intro. Mary Anne Schofield (Delmar, N.Y.: Scholars' Facsimiles \& Reprints, 1983) 247-48.

17 John Bender, Imagining the Penitentiary: Fiction and Architecture of Mind in Eighteenth-Century England (Chicago: U of Chicago P, 1987) 78.

18 Eliza Haywood (n. 2) 56.

19 Lawrence Stone, Uncertain Unions: Marriage in England 1660 -1753 (Oxford: Oxford UP, 1992) 14. 